\title{
TERORISME INTERNASIONAL DAN PENGARUH AL-QAEDA PASCA MENINGGALNYA OSAMA BIN LADEN
}

\author{
Agung Y. Nugroho, MA.
}

\begin{abstract}
al-Qaeda is one of the movement of global terrorism network that has a neat organizational structure and has established a strong chain of command and have an extensive network, greatly influenced by movements in sentiment toward the United States. WTC tragedy and other actions always lead to the infrastructure of Western countries, especially the U.S.. Osama Bin Laden as the leader of the al-Qaeda network has strong power in giving its influence in leading al-Qaeda. It can not be denied that Bin Laden was in first place most wanted people in the world. Under Bin Laden, al-Qaeda terrorist movement became a professional and highly coordinated, it can be seen from their actions is very neat.

Osama bin Laden's death in 2011 and then, for some people is the end of the story of al-Qaeda. But the name of al-Qaida continues to appear in the news all over the world. In the name of the late al-Qaeda has been attributed to several events in the form of bomb attacks in Iraq, killing and conflict in Mali, clashes in Yemen, and sporadic raids and several incidents of kidnapping in Afghanistan. Looking at some of these cases the question "How gait or lunge al-Qaeda terrorist network after the death of Osama Bin Laden?
\end{abstract}

Keywords: al-Qaeda, Terorism, Osama Bin Laden,United State of America, Afghanistan, International Security 


\section{A. Pendahuluan}

Terorisme telah menjadi momok bagi stabilitas dan keamanan internasional, teror yang diciptakan oleh gerakan-gerakan yang mengatasnamakan fundamental ideologi telah menempatkan dirinya dalam arus ketakukan yang berdampak signifikan bagi keamanan dan kenyaman dunia internasional. Terlebih lagi transnasionalis terorisme yang terakomodir dan mengancam langsung keselamatan setiap warga negara dimana teror yang diaplikasikan tersebut berlangsung.

Pasca tragedi 9 September 2001, terjadi perubahan drastis isu-isu global dibidang Internasional Security dan fokus utama setiap negara adalah kasus terorisme, hal ini kemudian menciptakan aturan-aturan baru yang mengarah pada penanganan kasus-kasus teror yang kemudian "diarahkan" oleh Amerika Serikat untuk menyerang Afganistan. Terorisme itu sendiri saat ini dapat dilihat sebagai suatu isu utama dalam percaturan dunia yang berkontruksi dalam sistem keamanan internasional. Patron dan arah dari terorisme dewasa ini lebih mengarah pada suatu penekanan pada suatu paham ideologi yang bagi masyarakat umum merupakan suatu isu yang sangat sensitif dikarenakan mengarah pada unsur agama yang notabene merupakan suatu keyakinan yang dianut oleh masing-masing individu.

Teror ini kemudian berkembang menjadi rasa ketidakpuasan akan suatu rejim yang menekan suatu ideologi atau agama tertentu. Dalam kontek terorisme global dewasa ini tidak bisa dilepaskan dari peran al-Qaeda yang merupakan teroris fundamentalis yang membawa isu agama sebagai suatu paham yang menekankan pada kebersamaan dan memiliki rasa antipati yang tinggi terhadap dominasi negara-negara barat khususnya Amerika Serikat. Arah dan tujuan al-Qaeda yang mengarah pada suatu teror global dan terorganisir dengan baik serta membawa ketakutan tersendiri bagi komunitas internasional. al-Qaeda memiliki jaringan struktural yang menglobal dibawah pemimpinannya yang kharismatik, Osama bin Laden. Dibawah kepemimpinan Osama bin Laden, al-Qaeda berubah menjadi jaringan teroris yang sangat 


\section{ditakuti dan sangat dominan dalam segala aksi teror di dunia pada satu dasawarsa terakhir ini.}

Kematian Osama bin Laden pada tahun 2011 lalu, bagi sebagian orang merupakan akhir dari cerita al-Qaeda. Akan tetapi nama al-Qaeda terus muncul dalam pemberitaan di seluruh dunia. Pada akhir-akhir ini nama al-Qaeda banyak dihubungkan dengan beberapa kejadian berupa serangan bom di Irak, pembunuhan dan konflik di Mali, bentrokan di Yaman, dan penyerangan-penyerangan sporadis dan beberapa insiden penculikan di Afganistan.

\section{B. Rumusan Masalah}

Dari uraian yang tersebut di atas, penulis mencoba untuk merumuskan masalah dalam penelitian ini sebagai berikut: Bagaimana kiprah atau sepak terjang Jaringan terorisme al-Qaeda pasca meninggalnya Osama Bin Laden ?

\section{Tujuan Penelitian}

Tujuan penelitian yang dilakukan adalah untuk mendeskripsikan Jaringan terorisme al-Qaeda pasca meninggalnya Osama Bin Laden.

\section{Metodologi Penelitian}

Di dalam penelitian ini penulis akan menggunakan tipe penelitian deskriptif analisis dengan memberikan suatu gambaran secara sistematis tentang fakta-fakta dan hubungan antara fenomena yang diteliti.

\section{E. Fokus Penelitian}

Untuk mengetahui secara jelas mengenai indikator-indikator yang akan diukur, maka perlu merumuskan fokus penelitian dalam penelitian ini. Adapun fokus penelitian sebagai berikut:

1. Terorisme Pasca tragedi 9/11. 
2. Sejauhmana sepak terjang Jaringan terorisme al-Qaeda pasca meninggalnya Osama Bin Laden.

\section{F. Pembahasan}

Isu terorisme menjadi isu global dengan ditandai runtuhnya World Trade Center (WTC) tanggal 11 September 2001. Peristiwa ini tidak hanya menjadi isu nasional terhadap Amerika dan sekutunya, tetapi juga menimbulkan isu di dunia Islam,dan semakin merenggangkan hubungan antara keduanya, karena setelah kejadian tersebut Presiden George W. Bush mengumumkan bahwa yang bertanggung jawab atas pengeboman WTC itu adalah jaringan Teroris al-Qaeda yang merupakan kelompok teroris yang berideologi Islam. Pernyataan secara sepihak dari Presiden Bush tersebut tanpa disertai wacana atas permasalahan dan statement resmi dari pemerintah Amerika sendiri, bahkan Bush memberi opsi yang sangat fenomenal “ Either with Us or with the terroris". Pernyataan yang terkesan menyudutkan umat Islam didunia ini telah menjadi pertanda akan ketidaksenangan Bush terhadap Teroris dan Islam khususnya. Hal ini terbukti setelah itu, Bush memberi pernyataan pada negara-negara yang dianggap menentang terhadap AS dengan sebutan "Axis of evil', mereka adalah Irak, Iran, Korea Utara.

Berbagai Pernyataan dilontarkan Amerika sebagai reaksi dari peristiwa teror yang terjadi di Amerika Serikat. Pendapat yang secara terang-terangan menyebut Islam sebagai agama yang menginspirasikan tindakan teror dan memproduksi kaum teroris, yang berdampak pada kebijakan mereka. Perlakuan dan investigasi secara berlebihan dilakukan, selain itu Amerika juga memberlakukan undang-undang atau prosedur tertentu untuk memantau para imigran dan pengunjung dari negara Islam. Dunia Islam pun merasa berada diantara respresi domestik dan perlakuan yang tidak mengenakan, serta berada dalam siatuasi yang terkondisikan di mata internasional, sehingga Negara-negara Islam banyak yang mengecam Amerika 
Ada beberapa hal yang harus kita telaah, ketika Amerika ikut andil atau mencampuri Dunia Muslim yang memiliki tradisi dan kultur yang sangat jelas berbeda, diantaranya yaitu tentang kepentingan Amerika serikat sebelum Perang Dunia kedua, dan invasi Amerika Serikat yang diiringi pemaksaan kesejumlah negara Islam yang menyebabkan dominasinya di dunia Islam. Amerika merupakan satu satunya negara super power setelahnya jatuhnya Uni Sovyet dalam perang dingin. Dalam tragedi 9 September terjadi banyak kejanggalan-kejanggalan, misalnya seperti salah satu media elektonik yang bisa memiliki akses untuk meliput mulai awal kejadian hingga akhir sepertinya mereka sudah diberi tahu sebelumnya, kejanggalan lainya adalah saham-saham di WTC habis terjual sebelum kejadian 911, dan masih banyak kejanggalan lainnya. Perlu disampaikan bahwa AS ini adalah sedang mengalami krisis Identitas saat itu. Mungkin ada beberapa pertanyaan yang bisa kita asumsikan kepada Amerika, seperti "Siapa Saya", "Apa kepentingan Saya”, dan “Image apa yang ingin saya bangun pada Dunia?". Sehingga, apabila kita Analisa melalui perspektif konstruktivisme, ada beberapa hal utama yang perlu kita kaitkan dengan tragedi ini, yaitu; Identitas, Norma dan nilai-nilai yang akan membentuk konstruksi sosial, Ide/Gagasan, dan Persepsi tentang “siapa saya?”. Peristiwa 9 september ini telah mengkonstitusikan dunia secara sosial melalui hubunganhubungan yang terjadi diantara dunia barat dan dunia Islam secara intersubjektif .yang secara implisit sengat memojokan islam.

Keamanan internasional pasca peristiwa 9 September, ditandai dengan Sistem keamanan yang telah berubah,setelah peristiwa ini,dimana konsep perang digunakan pada dekade ini.tragedi WTC dan respon Amerika Terhadap Terorisme merupakan awal dari terbangunya sebuah tatanan politik dunia yang ditandai mencuatnya ancaman non tradisional (khususnya dalam bentuk terorisme) dan hegemoni Amerika sebagai adidaya tunggal. Inilah yang pada saatnya akan memberikan penjelasan mengenai berbagai serangan yang dilakukan Amerika ke Daerah Timur Tengah,seperti serangan Amerika ke Afganistan dan Irak sebagai politik Global. 


\section{G. Karakter Terorisme}

Pada umumnya, strukturalisme menempatkan terorisme sebagai aksi kriminal. Akan tetapi, strukturalisme lebih menekankan pada faktor penyebab dari terorisme itu sendiri dan radikalisasi identitas ${ }^{1}$. Dalam hal ini, terorisme internasional dapat dilihat sebagai reaksi terhadap hegemoni global AS yang telah melakukan intervensi ekstensif, baik secara militer maupun politik, di berbagai kawasan dunia, termasuk di Timur Tengah, yang kemudian menumbuhkan perasaan anti-Amerika dan radikalisme di kawasan-kawasan tersebut.

Dengan demikian,struktur mendasar dari terorisme adalah keterlibatan AS secara militer-politik di berbagai kawasan dunia dan pemaksaan kepentingan AS dalam perpolitikan regional. Deprivasi relatif dan ketidaksetaraan struktural yang dibawa globalisasi pun dipandang sebagai faktor yang menyebabkan terorisme. Dengan demikian,terorisme dipandang sebagai reaksi terhadap tatanan global yang hirarkis dan tidak adil, yang di antaranya termanifestasikan dalam kebijakan luar negeri AS yang dominan, interventif, imperialis, dan hegemonik. Dalam 7 kerangka konseptualisasi teror dari Schmid, terorisme dari paradigma strukturalis dapat dipandang sebagaiaktivitas politik untuk mewujudkan tatanan baru yang lebih adil ${ }^{2}$.

\section{H. Jaringan Terorisme}

Pandangan strukturalisme mengenai jaringan terorisme dapat dikatakan sama dengan cara liberalisme memandangnya, yaitu terutama sebagai jejaring transnasional. Hal ini terjadi karena strukturalisme dan liberalisme sama-sama

\footnotetext{
${ }^{1}$ Jonathan Schanzer, 2004. “Al-Qaeda's Armies: Middle East Affiliate Groups \& The Next Generation of Terror." Washington Institute for Near East Policy

2 Karen J. Greenberg, 2005. “Al Qaeda Now: Understanding Today's Terrorists". Cambridge University Press, Cambridge.
} 
mengakui independensi aktor non-negara dan menentang pandangan yang statecentric $^{3}$.

Masalah terorisme internasional dewasa ini terutama gerakan dari fundamentalisme Islam akan sangat ditentukan oleh corak kebijakan AS itu sendiri. Hal ini dilihat dari politik tentang minya AS di timur tengah serta sikap AS terhadap konflik Palestina-Israel akan sangat menentukan laju gerak terorisme yang dilatarbelakangi dengan motivasi oleh ideologi dan agama ${ }^{4}$.

\section{Jaringan teroris al-Qaeda}

al-Qaeda adalah salah satu gerakan jaringan terorisme global yang mempunyai struktur organisasi yang rapi dan memiliki rantai komando yang terjalin kuat dan memiliki network yang luas, Dalam gerakannya sangat dipengaruhi oleh sentimen terhadap Amerika Serikat. Tragedi WTC dan aksi-aksi lainnya selalu mengarah pada infrastruktur negara-negara barat terutama AS. Osama Bin Laden sebagai pemimpin dari jaringan al-Qaeda memiliki power yang kuat dalam memberikan pengaruhnya dalam memimpin al-Qaeda. Hal ini tidak bisa dipungkiri bahwa Bin Laden menempati posisi pertama most wanted people in the world.

Di bawah Bin Laden, al-Qaeda menjadi gerakan teroris yang terstruktural dan sangat terkoordinir, ini bisa dilihat dari aksi-aksi mereka yang sangat rapi. CIA dan Intelijen internasional yang lain berkali-kali terkecoh dalam menyikapi dan mencegah aksi-aksi yang dilakukan oleh al-Qaeda. Beberapa aksi serangan teror yang dilakukan di WTC, Madrid Spanyol, dan London menjadi suatu contoh dimana aksiaksi regional yang dilakukan al-Qaeda mampu membawa pengaruh besar terhadap orientasi kebijakan dunia internasional.

Bagaimana nasib al-Qaeda setelah tewasnya Osama bin Laden? Diperkirakan kematian Osama tidak berpengaruh terhadap operasi al-Qaeda. Secara konseptual dan

${ }^{3}$ Ibid.

${ }^{4}$ Budi Winarno,2011. "Isu-Isu Global kotemporer". Cet 1,Yogyakarta,CAPS, hal. 183. 
ideologi kelompok ini tidak akan punah selama faktor-faktor yang mendorong eksistensinya masih bercokol di muka bumi. Tewasnya Osama hanya memberi dampak kemenangan psikologis, khususnya di Amerika Serikat dan dunia Barat. Pasca tragedi 11 September 2001 itu, sebenarnya Osama lebih sebagai simbol ketimbang pemegang komando atau perancang operasi. Bahkan, hubungan Osama dengan jaringan al-Qaeda di mana pun praktis putus ${ }^{5}$. Hidup Osama pun terisolasi. Opsi hidup terisolasi sudah menjadi pilihannya setelah tragedi 11 September 2001 itu dengan dalih keamanan. Namun, Osama telah mengubah al-Qaeda, dari Tanzim dengan sistem komando yang sentralistis menjadi jaringan dengan sistem desentralisasi komando di mana para loyalis al-Qaeda di seluruh dunia diberi otonomi luas untuk merancang dan melaksanakan operasinya ${ }^{6}$.

al-Qaeda pun bukan lagi berbentuk organisasi ketat, tetapi hanya sebagai payung ideologi. Perencanaan dan pelaksana operasi diserahkan sepenuhnya kepada organisasi atau tokoh regional al-Qaeda di berbagai negara. Karena itu, berbagai operasi al-Qaeda beberapa tahun terakhir ini lebih terindentifikasi pada al-Qaeda regional seperti al-Qaeda di Semenanjung Arab yang bertanggung jawab di Yaman dan Arab Saudi, al-Qaeda di bilad Rafidain yang bertanggung jawab di Irak, al-Qaeda di Maghrib Arab yang bertanggung jawab di Maroko, Aljazair, Tunisia, dan Libya, serta sel-sel dalam bentuk lebih kecil di AS, Eropa, Asia Tengah, dan Asia Tenggara ${ }^{7}$. Semua aksi kekerasan besar dalam sepuluh tahun terakhir ini dirancang dan dilaksanakan oleh tokoh atau simpatisan al-Qaeda regional yang jauh dari campur tangan Osama atau al-Qaeda pusat. Aksi kekerasan besar, seperti bom Bali (2002 dan 2005) dan lainnya di dunia, dilakukan pengagum Osama.

Kini sudah muncul pula tokoh-tokoh al-Qaeda regional yang sesungguhnya saat ini lebih berbahaya dari Osama bin Laden, di antaranya tokoh intelektual al-

\footnotetext{
${ }^{5}$ Rohan Gunaratna, 2003. “Inside Al Qaeda : Global Network of Terror”. Bsrklsy PubGroup

${ }^{6}$ Ibid.

${ }^{7}$ Ibid
} 
Qaeda di Semenanjung Arab, Anwar al Aulaqi (38), yang kini hidup di Yaman. Al Aulaqi adalah warga negara AS asal Yaman yang lahir di New Meksiko, AS, dan bekerja sebagai khatib di Masjid Dar al Hijrah di wilayah Virginia sebelum tragedi 11 September 2001. Serta Ayman al-Zawahiri, orang kedua jaringan al-Qaeda.

Para pengamat gerakan Islam memperkirakan Ayman al-Zawahiri, akan mengambil alih kepemimpinan organisasi setelah kepergian Osama bin Laden dalam operasi militer Amerika dekat ibukota Pakistan, Islamabad. Meskipun tim pengamat memperkirakan keberlangsungan jaringan al-Qaeda tetap pada tujuan yang sama sebagaimana direncanakan Osama bin Laden, namun tim lain melihatnya berbeda, bahwa organisasi tersebut akan melemah dan rapuh, atau menuju kehancuran karena prestasi yang dicapai revolusi Arab. Seorang pengamat politik dan dosen di Birzeit University, Dr Iyad Barghouti, memperkirakan kelanjutan jaringan al-Qaeda pada tujuan yang sama mengikuti pendirinya, Osama bin Laden dan percaya bahwa Ayman al-Zawahiri adalah penerus kepemimpinan organisasi ${ }^{8}$.

Sebagian besar literatur yang membahas tentang al-Qaeda tidak berbicara mengenai pengikut jaringan, tetapi gagasan itu diwujudkan beberapa kelompok di berbagai negara di dunia, semuanya dengan cara masing-masing maupun dengan caranya sendiri, organisasi-organisasi tersebut tidak terkait dengan pusat, di mana Bin Laden bertanggung jawab ${ }^{9}$. Sementara itu, seorang ahli yang kompeten di bidang gerakan Islam, Dr Walid al-Mudlal melihat bahwa gagasan yang dikembangkan bin Laden terkait hubungan dengan Barat akan terus berlanjut.

Mengacu adanya nama-nama historis terkait jaringan al-Qaeda, seperti Ayman al-Zawahiri, analis politik mengatakan tidak menutup kemungkinan adanya deretan nama-nama lain muncul sebagai pemimpin baru, atau organisasi merahasiakan nama pemimpin baru di masa depan dan tetap merahasiakannya.

\footnotetext{
${ }^{8}$ Ibid

${ }^{9}$ Jonathan Schanzer, Loc. Cit.
} 
Gagasan bin Laden kebanyakan mengacu pada kasus saat ini, diperkirakan ideologi al Qaeda akan terus muncul selama pembenaran pendudukan Israel di tanah Arab di satu sisi dan intervensi asing dalam urusan Arab dan dunia Islam serta mengatasnamakan kepentingan mereka untuk kepentingan negara-negara Arab dan Islam.

Kampanye Barat tentang pertempurannya dengan Islam, gagasan al-Qaeda akan tetap ada tanpa keraguan dan bertambah kuat dalam menghadapi kekuatan besar yang tidak dimiliki Negara-negara Arab. Pengamat politik, Khalid Amayreh tidak melihat bahwa jaringan al-Qaeda dibangun di atas sosok seorang karismatik, jika mereka meninggal atau hilang, organisasi rusak, menjelaskan bahwa jaringan alQaeda adalah organisasi "ideologis tidak terpengaruh oleh kematian atau menghilangnya $\operatorname{pimpinan}^{10}$." $^{2}$

Bin Laden dalam beberapa tahun terakhir menjadi tokoh simbolis, bukan seorang pemimpin pribadi yang tertarik dalam organisasi harian, bagaimanapun, alQaeda telah melemah, meskipun tidak muncul di media, terutama setelah revolusi Arab.

\section{J. Revolusi Arab dan Al-Qaeda}

Masa depan organisasi al-Qaeda menurut Amayreh dalam revolusi Arab menunjukkan kemandulan dan tidak berfungsinya gagasan al-Qaeda dalam membawa perubahan dan perubahan pemerintahan, membuktikan bahwa cara-cara damai dan demonstrasi massa lebih efektif dalam mewujudkan perubahan yang diinginkan ${ }^{11}$.

Amayreh, bagaimanapun tetap memperingatkan bahwa jaringan al-Qaeda tidak dapat diterima "karena gagasan jaringan bukan berpusat pada ijma' ideologi jihad Salafi yang didasarkan pada pertempuran dan perjuangan melawan orang

\footnotetext{
${ }^{10}$ Rohan, Op. Cit.

${ }^{11}$ Ibid.
} 
musyrik, kafir dan pemerintahan pro kafir, tidak berhenti sampai memperoleh kemenangan atau mati syahid ${ }^{12}$."

Sementara Mudallil menyatakan keyakinannya bahwa jaringan al-Qaeda akan melemah jika revolusi Arab terus berkembang dan mencapai tujuannya," dan bahwa ketergantungan terhadap kepentingan Barat akan memunculkan ideologi al-Qaeda lagi.

Dalam konteks yang sama Barghouti melihat bahwa keberhasilan bangsabangsa Arab menegaskan bahwa zaman telah berpihak pada rakyat ,bukan pada pemerintah dan organisasi kecil tidak akan punya tempat, organisasi ini terbentuk terutama pada ketidakmampuan massa untuk reformasi, dengan demikian peran jaringan akan hilang ketika tujuan yang diinginkan telah tercapai. Pengaruh besar terhadap orientasi kebijakan dunia internasional.

\section{K. Kesimpulan}

kematian Bin Laden bagi al-Qaeda merupakan langkah mundur akan tetapi bisa menjadi suatu booster bagi al-Qaeda sendiri untuk melakukan regenerasi atau pola aksi baru yang lebih universal. Jaringan al-Qaeda saat ini tidak lagi berada dalam satu garis komando akan tetapi lebih pada indoktrinisasi dan membawa pengaruh yang lebih siknifikan bagi terorisme regional untuk mengembangkan aksi mereka.

Al-Qaeda telah menurun dalam intensitas aksinya tetapi tidak dalam pengaruhnya". Meskipun kekuatan al-Qaeda telah melemah, akan tetapi kemampuannya untuk membentuk dan mempengaruhi kelompok serupa yang terbentang dari Afrika ke Timur Tengah dan Asia semakin meningkat. Tidak pada masa Bin laden dimana al-Qaeda terfokus pada satu rantai komando dan jaringannya yang tersebar diseluruh dunia dengan divisi tugas yang berbeda-beda sesuai fungsi dan tujuan masing-masing, Saat ini al-Qaeda lebih cenderung terfragmentasi dan banyak melakukan aksi sporadis dan tidak terstruktur. Hal ini dikarenakan visi dari

\footnotetext{
${ }^{12}$ Rohan, Loc. Cit
} 
Bin Laden untuk al-Qaeda sendiri adalah menyebarkan ideologi al-Qaeda tentang global Jihad untuk melawan musuh yang bertentangan dengan pemahaman mereka. Beberapa afiliasi di seluruh dunia telah mengadopsi ideologi al-Qaeda ini yang kemudian dimanfaatkan untuk tujuan regional mereka sendiri dan dengan demikian telah memberikan al-Qaeda dan ideologinya, serta visi bin Laden, sebuah kehidupan baru.

\section{DAFTAR PUSTAKA}

Bett, Richard, Conflict After the Cold War: Arguments on Causes of War and Peace, Macmillan Publishing Company, New York, 1994

Buzan, Barry, People, States and Fear: An Agenda for International Security Studies in the Post-Cold War Era, Lynne Reinner Publisher, Boulder. Colorado, 1991

Chomsky, Noam. 2006. Failed State: The Abused of Power and the Assault on Democracy. New York: Metropolitan Books

Greenberg, Karen J., Al Qaeda Now: Understanding Today's Terrorists. Cambridge University Press, Cambridge, 2005

Gunaratna,Rohan, Inside Al Qaeda : Global Network of Terror. Bsrklsy PubGroup, 2003 
Kiras, James D., 2005. "Terorism and Globalization". Dalam John Baylis \& Steve Smith (eds.) The Globalization of World Politics: An Introduction to International Relations. Third Edition, New York: Oxford University Press.

Kolodziej, Edward, Security and International Relations, Cambridge University Press,

Cambridge, 2005

Martin, Hans-Peter dan Harald Schumman, 2005. Jebakan Global: Serangan terhadap demokrasi dan kesejahteraan, Jakarta: Hastra Mitra-Institute For Global Justice

Robertson, Ann E., 2007. Terrorism and Global Security. New York: Fact on File, INC

Schanzer,Jonathan,Al-Qaeda's Armies: Middle East Affiliate Groups \& The Next Generation of Terror. Washington Institute for Near East Policy, 2004

Sukma, Rizal. 2003. “Keamanan Internasional Pasca-11 September 2001: Terorisme, Hegemoni AS dan Implikasi Regional" http://www.lfip.org/english/pdf/baliseminar/keamana\%20Int1\%20-\%20rizal\%20sukma.pdf

Viotti , Paul R. and Mark V. Kauppi, 2007. International Relations and World Politics: Security, Economy, Identity, Third Edition, Upper Saddle River, New Jersey: Pearson Education Inc 
Winarno, Budi,2011. “Isu-Isu Global kotemporer”.Cet 1,Yogyakarta,CAPS

Yani ,Yanyan Mochammad 2010. "Kemenangan Partai Demokrat dan Masa Depan Perang Global Melawan Terorisme”, http://pustaka.unpad.ac.id/wpcontent/uploads/2010/06/kemenangan_partai_demokrat_dan_masa_depan.p df 